\title{
Chemical and Microbial Quality of Groundwater in Siloam Village, Implications to Human Health and Sources of Contamination
}

\author{
John Ogony Odiyo * and Rachel Makungo \\ Department of Hydrology and Water Resources, University of Venda, Thohoyandou 0950, South Africa; \\ rachel.makungo@univen.ac.za \\ * Correspondence: john.odiyo@univen.ac.za; Tel.: +27-159-628-511
}

Received: 13 December 2017; Accepted: 8 February 2018; Published: 12 February 2018

\begin{abstract}
Due to inaccessibility of potable water, rural communities drill boreholes within their homesteads despite vulnerability to groundwater contamination and associated health risks. This study assessed the quality of groundwater, identified potential sources of contamination and potential human health risks in Siloam Village, South Africa. Statistical difference between similar water quality parameters at different sites was determined at a significance level $(\alpha)$ of 0.05 . Water quality parameters with serious potential health effects on human beings were correlated with selected water quality parameters to understand the nature of correlation and possible sources of contamination. Fluorides and nitrates had excessively high concentrations associated with tooth damage and pronounced skeletal fluorosis, and methaemoglobinaemia in infants and mucous membrane irritation in adults, respectively. There were statistically significant differences between means of most water quality parameters. Contrasting correlation of fluoride with calcium and $\mathrm{pH}$ indicated the need to further identify local sources and fluoride control mechanisms. Correlation of nitrate with chloride mostly indicated that faecal contamination is the potential source of high nitrates in groundwater. This requires further verification. Presence of total coliforms and E. coli in most boreholes indicated potential presence of faecal contamination. The need to educate borehole owners' on possible strategies to minimise groundwater pollution was identified.
\end{abstract}

Keywords: ANOVA; faecal contamination; fluorides; groundwater quality; health risks; nitrates

\section{Introduction}

Composition of precipitation, anthropogenic activities, geological structure and processes within an aquifer determine the quality of groundwater [1]. Dissolution of minerals within the soil, sediment, and bedrock contribute to different cations and anions in groundwater depending on the geology of an area. For example, natural geology has been found to contribute to high fluoride, calcium, and trace metal concentrations in Kwazulu Natal [2], water hardness in the Central Free State [3], fluoride concentrations in Limpopo, Northern Cape, North-West and KwaZulu-Natal Provinces [4], in South Africa. Dedzo et al. [5] and Basavarajappa et al. [6] associated weathering of rock minerals with groundwater chemistry in Central-East Cameroon and Kanata, India, respectively.

Poor and deteriorating groundwater quality associated with diverse anthropogenic sources is widespread in South Africa [7]. Faecal matter from pit latrines also has potential to contaminate groundwater, thereby threatening human health [8]. Despite the water quality problems associated with groundwater, most rural areas of South Africa located in semi-arid remote areas characterized by inadequate potable water supply are use groundwater for domestic purposes. Due to lack of access to potable water, residents in rural areas drill their own private boreholes without considering 
the potential sources of groundwater contamination. In these areas, boreholes are drilled within the vicinity of pit latrines and subsistence farms within the owners' homesteads.

Holland [9] confirmed microbial contamination of numerous village water supply boreholes that are sited close to pit latrines in basement areas of Limpopo Province. In the Tshitale-Hlanganani region of Limpopo Province boreholes drilled close to sanitary facilities (pit latrine and septic tanks) had high microbial contamination [10]. Similar cases have been noted in rural areas of Zimbabwe [11], South West Nigeria [12], Bihar State in India [13], amongst others. Dissolution of rocks and infiltration from pit-latrines were identified as sources of groundwater pollution in Kwale District, Kenya [14]. In Siloam Village, agricultural practices and washing of clothes within the vicinity of boreholes were associated with high concentrations of calcium, magnesium and nitrate in groundwater [15]. The current study is focused on determining the quality status of groundwater from private boreholes and implications for domestic use, as well as inferring possible sources of contamination. This will be used to inform private borehole owners of the quality status of their borehole water and suggest ways of minimising groundwater contamination. The study also builds up on previous studies and provide additional information on water quality status of Siloam Village which will aid in generating solutions and decision making. Odiyo and Makungo [16] determined that calcium and $\mathrm{pH}$ influence fluoride concentrations in groundwater in Siloam Village but did not determine the relationship between these parameters. The latter study associated low calcium concentration to the high concentration of fluoride, while increased fluoride concentrations were attributed to alkaline $\mathrm{pH}$ in some of the boreholes in Siloam Village. Correlation can assist in identifying the sources of pollution and the significance of the water quality parameters. This is crucial when developing strategies to minimise pollution. Correlation studies also aid in choosing parsimonious parameters for frequent determination of water quality status [17], since it is cumbersome and costly to regularly monitor all water quality parameters. Thus, this will aid in ensuring continuous monitoring of the quality of groundwater.

\section{Materials and Methods}

\subsection{Study Area}

Siloam Village (Figure 1) falls within the semi-arid Nzhelele area in Limpopo Province, South Africa. Nzhelele River is the main river with low and variable flow pattern due to low and unpredictable rainfall (average 350 to $400 \mathrm{~mm}$ ) within its catchment [18]. The area is characterized by basic extrusive basalt rocks of the Sibasa formation, Soutpansberg Group. Groundwater occurs in intergranular and fractured rocks with borehole yields ranging from 0.5 to $2 \mathrm{~L} / \mathrm{s}$ [19]. Within Nzhelele area, boreholes depths varies from 65 to $85 \mathrm{~m}$ while average depth to groundwater is 15-25 $\mathrm{m}$ [20]. The use of groundwater to supplement surface water and harvested rainwater supply is common in Siloam Village. In addition to one public borehole that exists in Siloam Village, most residents have drilled boreholes within their homesteads to supplement their water needs. 


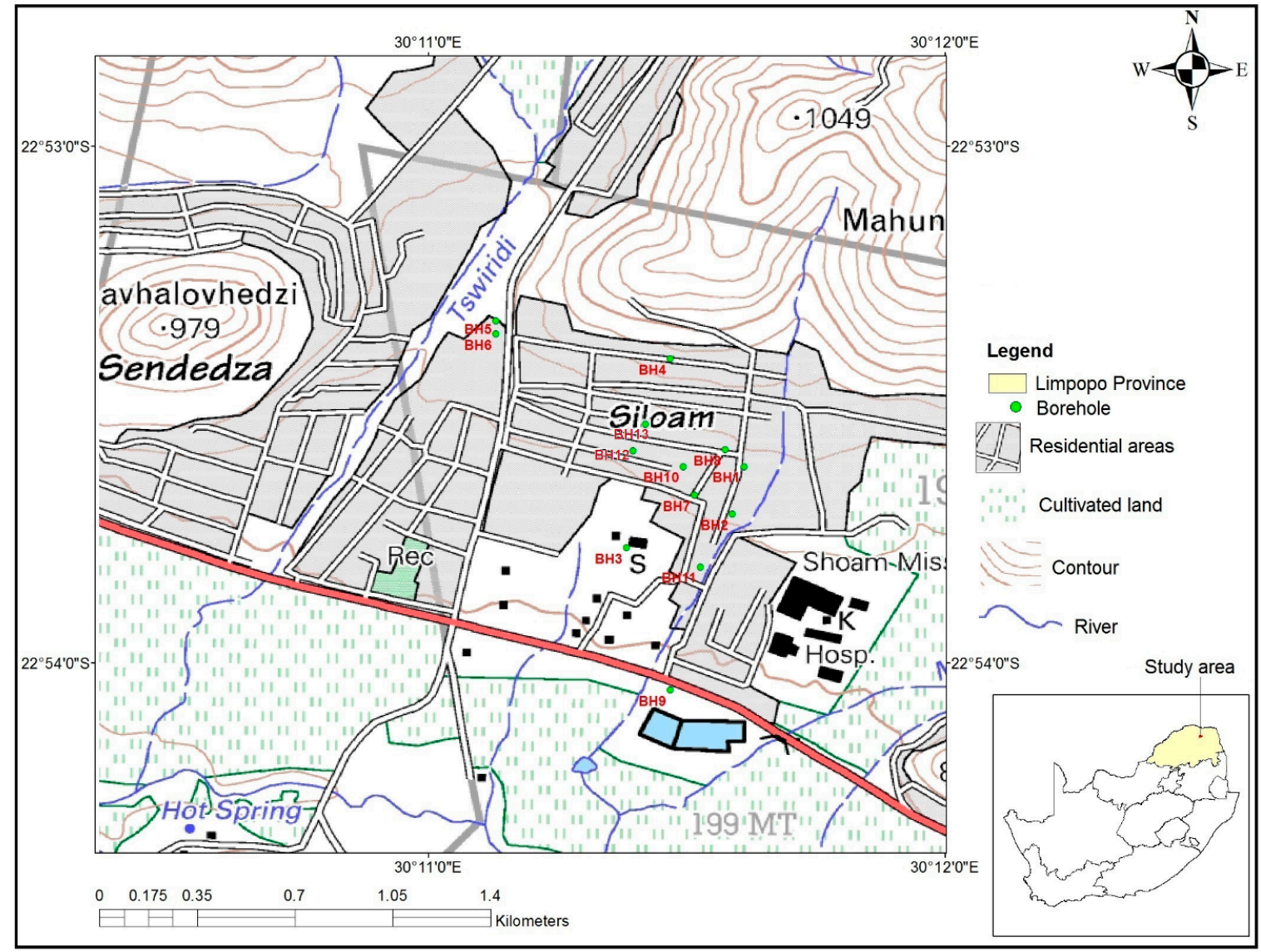

Figure 1. Location of the study area.

\subsection{Methods}

Groundwater samples from 11 boreholes in Siloam Village (BH1 to BH11 in Figure 1) were collected in sterile $1 \mathrm{~L}$ plastic containers and transported to the University of Venda research laboratory for physico-chemical analysis. The samples were collected once a month from August 2013 to January 2014. August and September 2013 fall in the dry season, while October to December 2013 and January 2014 are in the wet (rainfall) season. EC and pH were measured using Cyberscan PC510 benchtop meter while turbidity was measured using Eutech TN 100 turbidity meter. Samples were kept at 4-10 ${ }^{\circ} \mathrm{C}$ during transport to the laboratory. Non-metals (nitrates, fluoride, chloride, phosphate, sulphate) and metals (copper, manganese, zinc, calcium, potassium, magnesium, and iron) were analysed using 850 Professional Ion Chromatography (Anions Cation Metrohm Carbon dioxide Suppression (AnCat MCS) model, Metrohm (pty) Ltd., Pretoria, South Africa) and atomic absorption spectroscopy, respectively. These non-metallic and metallic parameters were selected because they are general indicators of water quality, which may lead to health problems [21], if they are in excessive concentrations. All equipment were calibrated following manufacturers' instructions and the samples were analysed in triplicate for quality assurance purposes. Samples were analysed within $24 \mathrm{~h}$ of collection. This is below the seven day period reported by the Department of Water Affairs and Forestry (DWAF) [22] for samples collected for chemical analysis, provided that they are kept in a cool environment.

Descriptive statistics (minimum, mean, maximum) were calculated to summarise the results of physico-chemical parameters and to assess the overall quality status of groundwater in the study area. The results were also compared with DWAF [23] target water quality ranges (TWQRs) for domestic use to infer the potential health risks. TWQR gives concentration range that have no effects on human health for a given water quality parameter. Water quality parameters with serious potential health 
effects on human beings were correlated with selected water quality parameters to understand the nature of correlation and possible sources of contamination. Relationships between fluoride with calcium and $\mathrm{pH}$ were determined from correlation coefficient at significance level $(\alpha)$ of 0.05 . This was aimed at establishing the control mechanism of fluoride in groundwater, and nature of correlation and significance of quality parameters on fluoride as suggested by [24,25]. Nitrates were also correlated with chloride and potassium to identify and determine potential sources of nitrate contamination. Statistical differences between similar water quality parameters at different sites was determined using single factor analysis of variance (ANOVA) within Microsoft Excel (2013, Microsoft, Johannesburg, South Africa). The tests were run at a significance level $(\alpha)$ of 0.05 .

Microbial quality indicators (total coliform, heterotrophic bacteria, Escherichia coli (E. coli) and faecal coliform were assessed in a previous study conducted by Mudau [26]. These were used to assess microbial status of groundwater and verify potential presence of faecal contamination of groundwater as indicated by the correlation between nitrates and chlorides. Total coliform and heterotrophic bacteria informed hygienic quality and general microbial quality of water while E. coli and faecal coliform indicated potential faecal contamination of groundwater.

\section{Results}

\subsection{Groundwater Quality and Implications to Human Health}

Descriptive statistics for water quality parameters for a six month period are in Tables 1 and 2. $\mathrm{pH}$ was mostly within TWQR of 6-9 except for maximum values for August, November, and December 2013, and January 2014, which were slightly above 9. Maximum and mean turbidity values for August 2013 and January 2014 exceeded TWQR of 0-1 NTU indicating chances of transmission of diseases by micro-organisms associated with particulate matter. Maximum and mean EC values were above TWQR of $070 \mathrm{mS} / \mathrm{m}$ for the entire period. Water is noticeably salty but is well tolerated and no health effects are likely to occur at EC values from 70 to $150 \mathrm{mS} / \mathrm{m}$ [23]. Water with EC values from 150 to $300 \mathrm{mS} / \mathrm{m}$ is associated with marked, salty taste, though it has no adverse health effects in the short term [23]. Maximum EC values for September, October, and December 2013 were only slightly above $150 \mathrm{mS} / \mathrm{m}$ and, therefore, may not pose serious aesthetic and health risks.

Minimum, mean, and maximum fluoride concentrations were above TWQR of $0-1 \mathrm{mg} / \mathrm{L}$ except for minimum concentration for August 2013 (Table 1). Minimum and mean fluoride concentrations mostly ranged from 1 to $5 \mathrm{mg} / \mathrm{L}$ which is associated with slight mottling of dental enamel in sensitive individuals [23]. Maximum fluoride concentrations for September to November 2013, and January 2014, and mean concentrations for October to November 2013 and January 2014 were within the range of 4 to $6 \mathrm{mg} / \mathrm{L}$ which can severely damage the teeth particularly those of infants and soften the enamel and dentine if water is used continuously [23]. Maximum fluoride concentrations for August and December 2013 were within the range of 6 to $8 \mathrm{mg} / \mathrm{L}$, which can severely damage teeth and cause pronounced skeletal fluorosis on long-term exposure [23].

Mean chloride concentrations for August and December 2013, and January 2014, and maximum for November 2013 exceeded DWAF [23] TWQR of 0 to $100 \mathrm{mg} / \mathrm{L}$ (Table 1), though they had no aesthetic or health effects. Maximum chloride concentrations for August to October 2013, December 2013 and January 2014 exceeded $200 \mathrm{mg} / \mathrm{L}$. Water with chloride concentrations exceeding $200 \mathrm{mg} / \mathrm{L}$ has a distinctly salty taste, but no health effects [23]. Mean and maximum nitrates were $>20 \mathrm{mg} / \mathrm{L}$ and, hence, exceeded TWQR of 0 to $6 \mathrm{mg} / \mathrm{L}$. Nitrate concentrations $>20 \mathrm{mg} / \mathrm{L}$ are associated with methaemoglobinaemia in infants and occurrence of mucous membrane irritation in adults [23]. Maximum sulphates for October and November 2013, and January 2014 exceeded a TWQR of $200 \mathrm{mg} / \mathrm{L}$. DWAF [23] indicated that water with sulphates exceeding $200 \mathrm{mg} / \mathrm{L}$ can cause diarrhoea and it is salty and bitter. Most metals were within their specific TWQR (Table 2), except for maximum and mean manganese concentrations for September 2013 to January 2014, and September and December 2013, respectively, which exceeded the TWQR of 0 to $0.05 \mathrm{mg} / \mathrm{L}$. Water with manganese concentrations 
from 0.05 to $0.1 \mathrm{mg} / \mathrm{L}$ is within tolerable range associated with no health effects [23]. Concentrations of $\mathrm{Mn}$ between 0.15 to 1.0 and 1.0 to $2.0 \mathrm{mg} / \mathrm{L}$ indicate thresholds for significant staining and very severe staining, respectively, though the water has no health effects [23]. Thus, maximum manganese concentrations in September and December 2013, and January 2014, which were $>0.15$, but $<1 \mathrm{mg} / \mathrm{L}$ could cause significant staining, but no health effects. Maximum iron concentrations in December 2013 and January 2014 ranged from of 0.1 to $0.3 \mathrm{mg} / \mathrm{L}$ which, has very slight effects on taste, but no health effects [23].

Table 1. Descriptive statistics for physical water quality parameters and non-metals.

\begin{tabular}{|c|c|c|c|c|c|c|c|c|}
\hline Parameter & $\begin{array}{l}\text { Descriptive } \\
\text { Statistic }\end{array}$ & $\begin{array}{c}\text { August } \\
2013\end{array}$ & $\begin{array}{l}\text { September } \\
2013\end{array}$ & $\begin{array}{c}\text { October } \\
2013\end{array}$ & $\begin{array}{l}\text { November } \\
2013\end{array}$ & $\begin{array}{l}\text { December } \\
2013\end{array}$ & $\begin{array}{c}\text { January } \\
2014\end{array}$ & TWQR \\
\hline \multirow{4}{*}{$\mathrm{pH}$} & Min & 7.14 & 7.27 & 7.22 & 7.00 & 7.26 & 6.83 & \multirow{4}{*}{$6-9$} \\
\hline & Max & 9.06 & 8.88 & 8.86 & 9.08 & 9.29 & 9.28 & \\
\hline & Mean & 7.68 & 7.87 & 7.75 & 7.83 & 7.88 & 7.86 & \\
\hline & STDEV & 0.53 & 0.54 & 0.69 & 0.83 & 0.64 & 0.89 & \\
\hline \multirow{4}{*}{$\begin{array}{l}\text { Turbidity } \\
\text { (NTU) }\end{array}$} & Min & 0.00 & 0.00 & 0.01 & 0.00 & 0.00 & 0.00 & \multirow{4}{*}{1} \\
\hline & Max & 25.91 & 0.89 & 0.55 & 0.47 & 0.69 & 11.85 & \\
\hline & Mean & 2.54 & 0.17 & 0.18 & 0.09 & 0.19 & 1.80 & \\
\hline & STDEV & 7.77 & 0.27 & 0.23 & 0.15 & 0.26 & 3.97 & \\
\hline \multirow{4}{*}{$\begin{array}{c}\mathrm{EC} \\
(\mathrm{mS} / \mathrm{m})\end{array}$} & Min & 34.90 & 36.60 & 43.80 & 36.10 & 23.68 & 30.10 & \multirow{4}{*}{70} \\
\hline & Max & 141.80 & 156.60 & 158.80 & 141.00 & 151.70 & 139.90 & \\
\hline & Mean & 81.96 & 90.83 & 86.02 & 84.68 & 85.63 & 90.33 & \\
\hline & STDEV & 38.10 & 43.07 & 40.94 & 33.95 & 43.77 & 42.27 & \\
\hline \multirow{4}{*}{$\begin{array}{c}\text { Fluoride } \\
\text { (mg/L) }\end{array}$} & Min & 0.00 & 1.40 & 1.52 & 1.51 & 1.17 & 1.34 & \multirow{4}{*}{1} \\
\hline & $\operatorname{Max}$ & 6.74 & 5.41 & 5.85 & 5.84 & 6.16 & 5.89 & \\
\hline & Mean & 3.82 & 3.69 & 4.60 & 4.01 & 3.82 & 4.16 & \\
\hline & STDEV & 2.41 & 1.64 & 1.59 & 1.92 & 2.01 & 1.64 & \\
\hline \multirow{5}{*}{$\begin{array}{l}\text { Chloride } \\
(\mathrm{mg} / \mathrm{L})\end{array}$} & Min & 5.73 & 0.00 & 0.00 & 0.00 & 24.89 & 0.00 & \multirow{5}{*}{100} \\
\hline & $\operatorname{Max}$ & 1177.40 & 223.58 & 223.13 & 198.22 & 296.27 & 410.86 & \\
\hline & Mean & 198.01 & 83.40 & 99.61 & 87.84 & 134.12 & 160.56 & \\
\hline & STDEV & 332.66 & 69.43 & 83.88 & 67.23 & 95.93 & 145.55 & \\
\hline & Min & 0.22 & 6.77 & 10.10 & 2.66 & 6.10 & 7.92 & \\
\hline \multirow{3}{*}{$\begin{array}{l}\text { Sulphate } \\
(\mathrm{mg} / \mathrm{L})\end{array}$} & Max & 188.36 & 64.18 & 365.36 & 313.79 & 174.58 & 404.01 & \multirow{3}{*}{200} \\
\hline & Mean & 34.45 & 24.07 & 80.20 & 43.75 & 44.99 & 70.12 & \\
\hline & STDEV & 53.14 & 20.33 & 140.29 & 95.30 & 54.39 & 126.57 & \\
\hline \multirow{4}{*}{$\begin{array}{l}\text { Nitrate } \\
(\mathrm{mg} / \mathrm{L})\end{array}$} & Min & 0.00 & 0.00 & 0.00 & 0.00 & 0.00 & 0.00 & \multirow{4}{*}{6} \\
\hline & Max & 137.04 & 409.93 & 65.51 & 209.94 & 596.42 & 543.27 & \\
\hline & Mean & 40.96 & 88.69 & 34.43 & 45.57 & 99.99 & 107.63 & \\
\hline & STDEV & 48.36 & 129.86 & 25.76 & 64.61 & 193.17 & 175.59 & \\
\hline
\end{tabular}

Note: Values in bold exceeded TWQR.

Table 2. Descriptive statistics for metals.

\begin{tabular}{|c|c|c|c|c|c|c|c|c|}
\hline Parameter & $\begin{array}{l}\text { Descriptive } \\
\text { Statistic }\end{array}$ & $\begin{array}{c}\text { August } \\
2013\end{array}$ & $\begin{array}{l}\text { September } \\
2013\end{array}$ & $\begin{array}{c}\text { October } \\
2013\end{array}$ & $\begin{array}{l}\text { November } \\
2013\end{array}$ & $\begin{array}{l}\text { December } \\
2013\end{array}$ & $\begin{array}{c}\text { January } \\
2014\end{array}$ & TWQR \\
\hline \multirow{4}{*}{$\begin{array}{l}\text { Magnesium } \\
(\mathrm{mg} / \mathrm{L})\end{array}$} & Min & 0.33 & 0.33 & 5.46 & 0.09 & 0.54 & 1.08 & \multirow{4}{*}{30} \\
\hline & Max & 10.86 & 11.19 & 11.26 & 11.22 & 10.57 & 11.27 & \\
\hline & Mean & 7.98 & 8.35 & 9.29 & 8.32 & 8.34 & 8.14 & \\
\hline & STDEV & 3.64 & 3.82 & 2.07 & 3.61 & 3.20 & 3.96 & \\
\hline \multirow{4}{*}{$\begin{array}{l}\text { Manganese } \\
(\mathrm{mg} / \mathrm{L})\end{array}$} & Min & 0.01 & 0.01 & 0.00 & 0.01 & 0.01 & 0.01 & \multirow{4}{*}{0.05} \\
\hline & Max & 0.04 & 0.56 & 0.10 & 0.14 & 0.27 & 0.23 & \\
\hline & Mean & 0.02 & 0.09 & 0.02 & 0.04 & 0.06 & 0.05 & \\
\hline & STDEV & 0.01 & 0.17 & 0.04 & 0.05 & 0.09 & 0.07 & \\
\hline
\end{tabular}


Table 2. Cont.

\begin{tabular}{|c|c|c|c|c|c|c|c|c|}
\hline Parameter & $\begin{array}{l}\text { Descriptive } \\
\text { Statistic }\end{array}$ & $\begin{array}{c}\text { August } \\
2013\end{array}$ & $\begin{array}{l}\text { September } \\
2013\end{array}$ & $\begin{array}{c}\text { October } \\
2013\end{array}$ & $\begin{array}{l}\text { November } \\
2013\end{array}$ & $\begin{array}{l}\text { December } \\
2013\end{array}$ & $\begin{array}{c}\text { January } \\
2014\end{array}$ & TWQR \\
\hline \multirow{4}{*}{$\begin{array}{l}\text { Potassium } \\
(\mathrm{mg} / \mathrm{L})\end{array}$} & Min & 0.30 & 0.38 & 0.45 & 0.34 & 0.00 & 0.76 & \multirow{4}{*}{50} \\
\hline & Max & 4.67 & 5.84 & 3.94 & 7.70 & 8.67 & 7.30 & \\
\hline & Mean & 2.01 & 2.12 & 1.78 & 2.89 & 2.36 & 2.77 & \\
\hline & STDEV & 1.48 & 1.95 & 1.27 & 2.70 & 2.96 & 2.04 & \\
\hline \multirow{4}{*}{$\begin{array}{l}\text { Copper } \\
(\mathrm{mg} / \mathrm{L})\end{array}$} & Min & 0.00 & 0.00 & 0.01 & 0.01 & 0.00 & 0.01 & \multirow{4}{*}{1} \\
\hline & Max & 0.02 & 0.02 & 0.09 & 0.04 & 0.01 & 0.21 & \\
\hline & Mean & 0.01 & 0.00 & 0.02 & 0.02 & 0.01 & 0.03 & \\
\hline & STDEV & 0.01 & 0.01 & 0.03 & 0.01 & 0.00 & 0.07 & \\
\hline \multirow{4}{*}{ Zinc (mg/L) } & Min & 0.00 & 0.00 & 0.01 & 0.00 & 0.00 & 0.01 & \multirow{4}{*}{3} \\
\hline & Max & 0.05 & 0.30 & 0.84 & 0.37 & 1.00 & 0.88 & \\
\hline & Mean & 0.01 & 0.06 & 0.16 & 0.08 & 0.15 & 0.22 & \\
\hline & STDEV & 0.01 & 0.09 & 0.33 & 0.12 & 0.33 & 0.30 & \\
\hline \multirow{4}{*}{$\begin{array}{l}\text { Calcium } \\
(\mathrm{mg} / \mathrm{L})\end{array}$} & Min & 0.03 & 0.00 & 0.05 & 0.07 & 0.00 & 0.02 & \multirow{4}{*}{32} \\
\hline & Max & 4.12 & 1.89 & 5.25 & 4.67 & 3.26 & 5.59 & \\
\hline & Mean & 0.78 & 0.38 & 1.40 & 1.44 & 0.77 & 1.35 & \\
\hline & STDEV & 1.20 & 0.67 & 2.01 & 1.59 & 1.17 & 1.94 & \\
\hline \multirow{4}{*}{ Iron (mg/L) } & Min & 0.00 & 0.00 & 0.00 & 0.00 & 0.00 & 0.00 & \multirow{4}{*}{0.1} \\
\hline & Max & 0.00 & 0.01 & 0.00 & 0.06 & 0.14 & 0.17 & \\
\hline & Mean & 0.00 & 0.00 & 0.00 & 0.01 & 0.02 & 0.02 & \\
\hline & STDEV & 0.00 & 0.00 & 0.00 & 0.02 & 0.05 & 0.06 & \\
\hline
\end{tabular}

Note: Values in bold exceeded TWQR.

\subsection{ANOVA and Correlations}

Results of ANOVA test (Table 3) showed statistically significant difference between means of most of the water quality parameters since $p$-values were less than 0.05 , except for chloride, copper and zinc. Misi [27] reported no significant differences $(p>0.05)$ between mean values of $\mathrm{pH}$, turbidity, EC, chloride, fluoride, iron, zinc, and copper across sampling sites located in basement aquifer of Upper Manyame Sub-catchment in Zimbabwe. This was explained to be due to the fact that sampling was conducted in the rainy season, hence, less variation could be expected due to the dilution effect from the rain. Sampling period in the current study partially covered both dry and rainy seasons showing that variations in rainfall possibly resulted in significant differences between means of most of the water quality parameters. Mean values for chloride, copper and zinc were, however, not affected by seasonal variations in rainfall since their $p$-values were higher than 0.05 .

Table 3. Statistical significance based on single factor ANOVA.

\begin{tabular}{ccc}
\hline Parameter & $p$-Value & Statistical Significance \\
\hline $\mathrm{pH}$ & $6.69444 \times 10^{-12}$ & Yes \\
EC & $4.1007 \times 10^{-19}$ & Yes \\
Turbidity & $3.03 \times 10^{-2}$ & Yes \\
Fluoride & $7.98306 \times 10^{-15}$ & Yes \\
Chloride & 0.5255362 & No \\
Sulphate & $6.17901 \times 10^{-10}$ & Yes \\
Nitrate & $1.28 \times 10^{-4}$ & Yes \\
Manganese & $6.46 \times 10^{-3}$ & Yes \\
Potassium & $1.94 \times 10^{-7}$ & Yes \\
Copper & 0.2159 & No \\
Zinc & 0.1658 & No \\
Iron & $1.05 \times 10^{-2}$ & Yes \\
\hline
\end{tabular}


Nitrates and fluorides were the only parameters with excessively high concentrations in groundwater which are associated with health effects on human beings, and their correlation with related parameters was determined. Negative correlation between calcium and fluoride was found in seven of the boreholes while four had positive correlation (Table 4). The contrasting correlations is an indication of the local variations of geological formations that are in contact with groundwater within the aquifer. This has resulted to the spatial variations in fluoride concentrations in the study area (Figure 2). Though surface geology around all boreholes in the area is similar, it is possible that there are variations in geology in the deep formations where groundwater is found. Odiyo and Makungo [16] associated increase in calcium with decrease in fluoride in Siloam Village, thereby, suggesting negative correlation of the two variables. The results of the latter study were, however, limited to three sites (two boreholes and one hotspring) which are excluded in the current study. Negative correlation between fluoride and calcium is attributed to low solubility of fluoride from fluoride bearing rocks [28], suggesting the possibility of ion-exchange process [29].

Table 4. Correlation of fluoride with calcium and $\mathrm{pH}$.

\begin{tabular}{cccc}
\hline Site & Calcuim & $\mathbf{p H}$ & Fluoride Ranges \\
\hline BH1 & 0.14 & 0.68 & $4.38-6.74$ \\
BH2 & -0.31 & -0.75 & $5.03-6.40$ \\
BH3 & -0.94 & -0.94 & $1.70-4.76$ \\
BH4 & 0.06 & 0.77 & $1.34-1.66$ \\
BH5 & -0.55 & -0.31 & $1.17-1.57$ \\
BH6 & 0.12 & -0.15 & $1.46-1.55$ \\
BH7 & -0.29 & -0.04 & $5.40-5.78$ \\
BH8 & -0.30 & 0.04 & $4.81-5.89$ \\
BH9 & -0.39 & 0.11 & $2.69-4.81$ \\
BH10 & -0.96 & -0.70 & $0.00-2.79$ \\
BH11 & 0.63 & 0.34 & $4.20-5.77$ \\
\hline
\end{tabular}

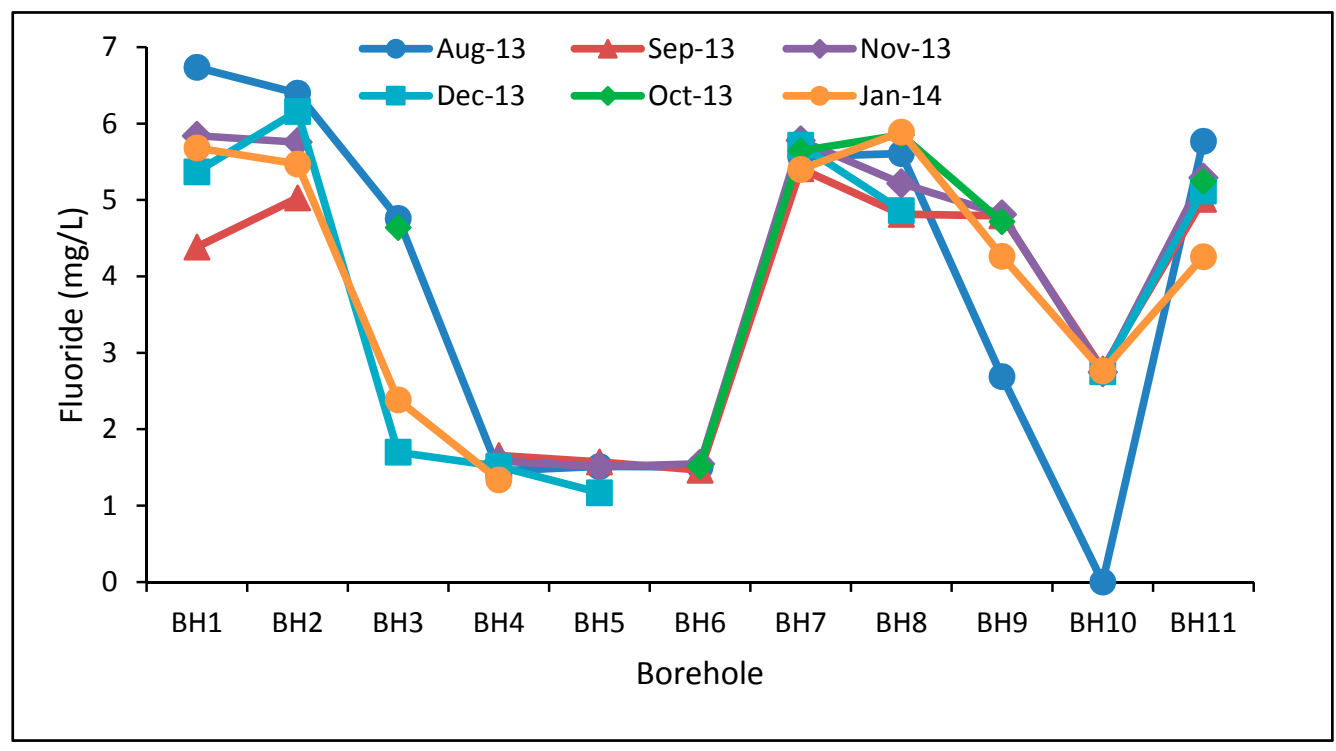

Figure 2. Variations of fluoride concentrations.

Ncube [4] reported negative correlation of calcium and fluoride for a borehole in Stelnberg and positive correlation for boreholes in Tugela and Zalexbayi in South Africa. Negative correlations were associated with moderate fluoride concentrations $(0.3-1.0 \mathrm{mg} / \mathrm{L})$ while positive correlations were associated with low and high fluoride concentrations. The results of this study did not follow this trend. For example, BH2 with high fluoride concentrations $(5.03-6.40 \mathrm{mg} / \mathrm{L}$ ) and BH5 with low 
concentrations (1.17-1.57 mg/L) had negative correlation while BH4 with low fluoride concentrations (1.34-166 mg/L) and BH1 with high concentrations $(4.38-6.74 \mathrm{mg} / \mathrm{L})$ had a positive correlation (Table 4). Odiyo and Makungo [16] reported increased fluoride concentrations resulted from reduced dilution effect on groundwater chemical composition due to arid/dry conditions in Siloam Village. In addition, the fluorite, which is a fluoride bearing rock, was identified as the likely source of fluoride in Siloam Village in the latter study. This indicates that further investigations are required to identify the local sources and fluoride control mechanisms in the study area. Chakraborti [30] reported positive correlation of fluoride with calcium in groundwater in Assam, India, which [31] attributed to the presence of limestone in that area. Avtar et al. [32] indicated positive correlation between $\mathrm{pH}$ and calcium with groundwater in Chhatarpur area, Madhya Pradesh, India. The correlation between calcium and fluoride was linked to minerals like fluorspar, apatite, and fluorapatite. Liu et al. [33] noted that positive correlation between $\mathrm{Ca}$ and $\mathrm{F}$ indicated that they have the same origin.

Correlation between $\mathrm{pH}$ and $\mathrm{F}$ in five of the boreholes was positive, while the rest had negative correlation. A positive relationship with $\mathrm{pH}$ indicates towards a possible leaching of fluoride under high alkaline conditions of water [29]. Negative correlation between $\mathrm{pH}$ and $\mathrm{F}$ and positive correlation between $\mathrm{Ca}$ and $\mathrm{F}$ was reported in Iran [34]. Umarani and Ramu [35] reported that negative correlation of $\mathrm{pH}$ and $\mathrm{F}$ in groundwater from Tamilnadu, India, indicated though fluoride concentrations were low $(0.02$ to $1.54 \mathrm{mg} / \mathrm{L})$, they could still dissolve in groundwater. Fluoride concentrations in the latter study were within. Nephalama and Muzerengi [36] also attributed negative correlation of $\mathrm{pH}$ and F to low levels of fluoride in the rock in Masisi Village in Limpopo Province, South Africa where fluoride concentrations ranged from 0.31 to $0.94 \mathrm{mg} / \mathrm{L}$. In the current study, $\mathrm{BH} 5, \mathrm{BH} 6$ and $\mathrm{BH} 10$ had negative correlation of $\mathrm{pH}$ and $\mathrm{F}$, and relatively low $\mathrm{F}$ concentrations which ranged from 1.17 to 1.57, 1.46 to 1.55 , and 0.00 to $2.79 \mathrm{mg} / \mathrm{L}$, respectively (Table 4 and Figure 2). Thus, these low concentrations are likely to indicate low fluoride concentrations in the rocks at these sites and, therefore, explains negative correlation between $\mathrm{F}$ and $\mathrm{pH}$. These findings therefore show variable occurrence of fluoride bearing rocks in the study area.

BH1 and BH7 had relatively high positive correlations of potassium and nitrates (Table 5). Correlation between potassium and nitrates indicates that contamination is mainly from fertilizers [37]. BH3, BH4, BH6, BH7, BH8, and BH11 had positive high correlation of nitrates and chlorides (Table 5). Correlation between chlorides and nitrates indicates that contamination is mainly from animal and human wastes [37]. The boreholes are located within homesteads where there are no animals or livestock that can generate animal waste which has potential to pollute groundwater. Thus, the only likely source of groundwater contamination is faecal matter from pit latrines which are within the vicinity of the boreholes. However, further studies are required verify to if faecal matter is the source of nitrate contamination of groundwater in Siloam Village. The distances between pit latrines and boreholes in the study area as measured by Mukhumo [38] and presented in Table 5, show that boreholes are within proximity of pit latrines. The recommended minimum safe distance between point source of groundwater supply and pit latrine should be $>50 \mathrm{~m}$ [39]. Thus, there is high risk of groundwater contamination by human wastes in Siloam Village. Mudau [26] showed that there is contamination of groundwater by faecal matter from pit latrines that are not placed at an appropriate distance from the boreholes in Nzhelele area including Siloam Village. Results from [11] indicated that pit latrines impacted on microbiological groundwater quality up to $25 \mathrm{~m}$ lateral distance. The ease through which aquifer material/geology restricts or permits movement of microbial contaminants into the aquifer influences the distance up to which microbial contamination of groundwater occurs. Bessong et al. [40] indicated that microbial contamination of groundwater was reduced due to local geological barriers within the aquifer and/or filtration through attachment to soil media. 
Table 5. Correlation of nitrate with chloride and potassium.

\begin{tabular}{cccc}
\hline Site & Chloride & Potassium & Distance between Pit Latrines and Boreholes \\
\hline BH1 & -0.17 & 0.64 & 35 \\
BH2 & -0.61 & 0.01 & 40 \\
BH3 & 0.46 & -0.68 & $24,38,46^{*}$ \\
BH4 & 0.99 & -0.02 & 24 \\
BH5 & -0.06 & 0.01 & 18 \\
BH6 & 0.67 & -0.18 & 47 \\
BH7 & 0.99 & 0.48 & 34 \\
BH8 & 0.84 & -0.31 & 27 \\
BH9 & -0.36 & -0.30 & 45 \\
BH10 & -0.35 & -0.42 & 30 \\
BH11 & 0.84 & -0.31 & 23.3 \\
\hline
\end{tabular}

* Borehole surrounded by 3 pit latrines.

Microbial water quality indicators obtained in boreholes BH12 and BH13 (Figure 1) in Table 6 mostly exceeded their specific TWQR. This indicated a high risk of infectious disease transmission [26]. Studies done in rural areas of South Africa (for example, Potgieter et al. [10], Mpenyana-Monyatsi et al. [41], Palamuleni and Akoth [42]) have also indicated that faecal contamination of groundwater poses health risks to communities. Faecal coliform and E. coli are indicators of faecal pollution of water and their presence in most of the boreholes, though determined within a different study period, therefore, support the high correlation of nitrates and chloride obtained in the current study.

Table 6. Microbial water quality indicators.

\begin{tabular}{cccccc}
\hline \multirow{2}{*}{ Site } & Sampling Date & Total Coliform & Heterotrophic Bacteria & E. coli & Faecal Coliform \\
\cline { 2 - 6 } & TWQR & $\mathbf{0 - 5}$ & $\mathbf{0 - 1 0 0}$ & $\mathbf{0}$ & $\mathbf{0}$ \\
\hline \multirow{4}{*}{ BH12 } & 14 September 2009 & 211 & NM & 0 & NM \\
& 16 October 2009 & 0 & NM & 71 & NM \\
& 9 March 2010 & 121 & 365 & 120 & 22 \\
\hline \multirow{3}{*}{ BH13 } & 7 April 2010 & 219 & 370 & 130 & 34 \\
\hline & 14 September 2009 & 54 & NM & 0 & NM \\
& 16 October 2009 & 0 & 249 & 0 & NM \\
& 9 March 2010 & 68 & 403 & 21 & 50 \\
\hline
\end{tabular}

$\mathrm{NM}=$ not measured

\section{Conclusions}

The study showed that nitrates and fluorides were the only parameters with excessively high concentrations in groundwater which are associated with health effects on human beings. Potential risks associated with high concentrations of fluorides and nitrates include tooth damage and pronounced skeletal fluorosis on long-term exposure, and methaemoglobinaemia in infants and the occurrence of mucous membrane irritation in adults, respectively. The means of most of the water quality parameters were statistically different, as shown from the results of the ANOVA test.

Though earlier studies have identified potential sources of fluoride in Siloam Village, the contrasting correlations obtained with calcium and $\mathrm{pH}$ in this study indicate the need for further investigations to identify the local sources and fluoride control mechanisms in the study area. Microbial contamination of groundwater mainly from pit latrines was also identified. Subsistence farming was also found to contribute to nitrate pollution in some of the boreholes. There is a need to discuss possible strategies to minimise groundwater pollution with borehole owners in Siloam Village. These include relocation of pit latrines to acceptable distances from boreholes and efficient application of fertilizers to only the levels required by the crops. 
Acknowledgments: The Research and Publications Committee of the University of Venda is acknowledged for providing funds for covering the costs to publish in open access.

Author Contributions: Rachel Makungo assisted by students conducted field collection of water samples and analysis of physical water quality parameters. This also included laboratory analysis of metals and non-metals in groundwater. Rachel Makungo compiled the map of the study area, conducted descriptive statistics and ANOVA tests, and drafted the manuscript. John Ogony Odiyo conceptualised and designed the study, performed the correlation analysis, and revised and finalised the manuscript. John Ogony Odiyo also contributed reagents and materials used in both field and laboratory work.

Conflicts of Interest: The authors declare no conflict of interest.

\section{References}

1. André, L.; Franceschi, M.; Pouchan, P.; Atelia, O. Using geochemical data and modelling to enhance the understanding of groundwater flow in a regional deep aquifer, Aquitaine Basin, South-West of France. J. Hydrol. 2005, 305, 40-62. [CrossRef]

2. Sherman, H.M. The Assessment of Groundwater Quality in Rural Communities: Two Case Studies from KwaZulu-Natal. Master's Thesis, University of Natal, Durban, South Africa, 1998.

3. Esterhuizen, L.; Fossey, A.; Potgieter, E. Groundwater quality on dairy farms in central South Africa. Water $S A$ 2015, 41, 194-198. [CrossRef]

4. Ncube, E.J. The Distribution of Fluoride in South African Groundwater and the Impact There of on Dental Health. Master's Thesis, University of Pretoria, Pretoria, South Africa, 2006.

5. Dedzo, M.G.; Tsozué, D.; Mimba, M.E.; Tedd, F.; Nembungwe, R.M.; Linida, S. Importance of rocks and their weathering products on groundwater quality in Central-East Cameroon. Hydrology 2017, 4, 23. [CrossRef]

6. Basavarajappa, H.T.; Manjunatha, M.C.; Pushpavathi, K.N. Rock-water interaction and chemical quality analysis of groundwater in hard rock terrain of Chamrajanagara District, Karnataka, India using geoinformatics. J. Org. Inorg. Chem. 2015, 1, 1-11.

7. DWA. Groundwater Strategy 2010; Department of Water Affairs: Pretoria, South Africa, 2010; p. 64.

8. Graham, J.P.; Matthew, L.P. Pit latrines and their impacts on groundwater quality: A systematic review. Environ. Health Perspect. 2013, 121, 521-530. [CrossRef] [PubMed]

9. Holland, M. Hydrogeological Characterisation of Crystalline Basement Aquifers within the Limpopo Province, South Africa. Ph.D. Thesis, University of Pretoria, Pretoria, South Africa, 2011.

10. Potgieter, N.; Mudau, L.S.; Maluleke, F.R.S. Microbiological quality of groundwater sources used by rural communities in Limpopo Province, South Africa. Water Sci. Technol. 2006, 54, 371-377. [CrossRef] [PubMed]

11. Dzwairo, B.; Hoko, Z.; Love, D.; Guzha, E. Assessment of the impacts of pit latrines on groundwater quality in rural areas: A case study from Marondera district, Zimbabwe. Phys. Chem. Earth 2006, 31, 779-788. [CrossRef]

12. Adekunle, I.M.; Adetunji, M.T.; Gbadebo, A.M.; Banjoko, O.B. Assessment of groundwater quality in a typical rural settlement in Southwest Nigeria. Int. J. Environ. Res. Public Health 2007, 4, 307-318. [CrossRef] [PubMed]

13. Sorensen, J.P.R.; Sadhu, A.; Sampath, G.; Sugden, S.; Gupta, S.D.; Lapworth, D.J.; Marchant, B.P.; Pedley, S. Are sanitation interventions a threat to drinking water supplies in rural India? An application of tryptophan-like fluorescence. Water Res. 2016, 88, 923-932. [CrossRef] [PubMed]

14. Mzuga, J.M.; Tole, M.P.; Ucakuwun, E.K. The impact of geology and pit latrines on groundwater quality in Kwale District. In Dunes, Groundwater, Mangroves and Birdlife in Coastal Kenya; Hoorweg, J., Ed.; Acts Press: Nairobi, Kenya, 1998; pp. 85-96. ISBN 9966-41-101-1.

15. Odiyo, J.O.; Makungo, R. Water Quality Problems and Management in Rural Areas of Limpopo Province, South Africa, Water Pollution XI; WIT Transactions on Ecology and the Environment: Southampton, UK, 2012; Volume 164, pp. 135-146.

16. Odiyo, J.O.; Makungo, R. Fluoride concentrations in groundwater and human health impact in Siloam Village, Limpopo Province, South Africa. Water SA 2012, 38, 731-736. [CrossRef]

17. Patel, J.Y.; Vaghani, M.V. Correlation study for assessment of water quality and its parameters of par river Valsad, Gujarat, India. IJIERE 2015, 2, 150-156. 
18. Ashton, P.; Love, D.; Mahachi, H.; Dirks, P. An Overview of the Impacts of Mining and Mineral Processing Operations on Water Resources and Water Quality in the Zambezi, Limpopo and Olifants Catchments in Southern Africa; MMSD Southern Africa Research Reports, Report No. ENV-P-C 2001-042; International Institute for Environment and Development: London, UK, 2001; p. 336.

19. Du Toit, W.H.; Mulin, H.; Jonck, F. 1:500,000 Hydrogeological Map Series of the Republic of South Africa, Messina 2230, 1st ed.; DWAF: Pretoria, South Africa, 2002.

20. Busari, O. Groundwater in the Limpopo Basin: Occurrence, use and impact. Environ. Dev. Sustain. 2008, 10, 943-957. [CrossRef]

21. DWAF; DoH; WRC. Volume 1: Assessment Guide. In Quality of Domestic Water Supplies, 2nd ed.; Water Research Commission No: TT 101/98; DWAF: Pretoria, South Africa, 1998.

22. DWAF; DoH; WRC. Volume 2: Sampling Guide. In Quality of Domestic Water Supplies, 1st ed.; Water Research Commission No: TT 117/99; DWAF: Pretoria, South Africa, 2000.

23. DWAF. Volume 1: Domestic water use. In South African Water Quality Guidelines, 2nd ed.; DWAF: Pretoria, South Africa, 1996; p. 216.

24. Reza, R.; Singh, S. Groundwater quality status with respect to fluoride contamination in industrial area of Angul District Orissa India. Indian J. Sci. Res. Technol. 2013, 1, 54-61.

25. Alagumuthu, G.; Rajan, M. Monitoring of fluoride concentration in groundwater of Kadayam Block of Tirunelveli District, India: Correlation with physico-chemical parameters. Rasayan J. Chem. 2008, 1, 920-928.

26. Mudau, T.C. Effects of Pit Latrines Location on Groundwater of Nzhelele Village within Limpopo Province. Ph.D. Thesis, University of Venda, Thohoyandou, South Africa, 2011.

27. Misi, A. 2016 Assessment of Groundwater Potential and Vulnerability in the Upper Manyame Sub-Catchment of Zimbabwe. Master's Thesis, University of Zimbabwe, Harare, Zimbabwe, 2016.

28. Sharma, R.; Shah, S.; Mahanta, C. Hydrochemical study of groundwater fluoride. Asian J. Water Environ. Pollut. 2005, 2, 47-54.

29. Chakrabarty, S.; Sarma, H.P. Fluoride geochemistry of groundwater in parts of Brahmaputra flood plain in Kamrup district, Assam, India. Arch. Appl. Sci. Res. 2011, 3, 37-44.

30. Chakraborti, D.; Chanda, C.R.; Samanta, G.; Chowdhury, U.K.; Mukherjee, S.C.; Pal, A.B. Fluorosis in Assam, India. Curr. Sci. 2000, 78, 1421-1423.

31. Dutta, J.; Nath, M.; Chetia, M.; Misra, A.K. Monitoring of fluoride concentration in ground water of Small Tea Gardens in Sonitpur District, Assam, India: Correlation with physico-chemical parameters. Int. J. ChemTech Res. 2010, 2, 1199-1208.

32. Avtar, A.; Kumar, P.; Surjan, A.; Gupta, L.N.; Roychowdhury, K. Geochemical processes regulating groundwater chemistry with special reference to nitrate and fluoride enrichment in Chhatarpur area, Madhya Pradesh, India. Environ. Earth Sci. 2013, 70, 1699-1708. [CrossRef]

33. Liu, M.; Mande, S.-L.A.-S.; Zhang, Y.; Chen, H. Geochemical evaluation and nitrate in groundwater: A case study from Qinkenpao area, Daqing, China. Afr. J. Agric. Res. 2014, 2, 2992-3000.

34. Dobaradaran, S.; Mahvi, A.M.; Dehdashti, S.; Dobaradaran, S.; Shoara, R. Correlation of fluoride with some inorganic constituents in groundwater of Dashtestan, Iran. Fluoride 2009, 42, 50-53.

35. Umarani, P.; Ramu, A. Fluoride contamination status of groundwater in East Coastal area in Tamilnadu, India. IJIRSET 2014, 3, 10045-10051.

36. Nephalama, A.; Muzerengi, C. Assessment of the influence of coal mining on groundwater quality: Case of Masisi Village in the Limpopo Province of South Africa. In Proceedings of the Freiberg/Germany, Mining Meets Water-Conflicts and Solutions (IMWA 2016), Leipzig, Germany, 11-15 July 2016; pp. 430-438.

37. Alvi, S.K.; Khan, F.A.; Siddiqui, I.U.; Usmani, T.H.; Mahmood, S.N. Nitrate/nitrate contamination in groundwater of Karachi and its correlation with other physicochemical parameters. J. Chem. Soc. Pak. 2005, 27, 490-495.

38. Mukhumo, V. Investigating Suitability of Groundwater for Domestic Use in Siloam Village. Honours Dissertation, University of Venda, Thohoyandou, South Africa, 2014.

39. Xu, Y.; Braune, E. Minimum distance as an important concept for borehole source protection in South Africa. In Proceedings of the Ground Water 1995 Conference, Midrand, South Africa, 26-28 September 1995.

40. Bessong, P.O.; Odiyo, J.O.; Musekene, N.J.; Tessema, A. Spatial distribution of diarrhoea and microbial quality of domestic water during an outbreak of diarrhoea in the Tshikuwi Community in Venda, South Africa. J. Health Popul. Nutr. 2009, 27, 652-659. [CrossRef] [PubMed] 
41. Mpenyana-Monyatsi, L.; Onyango, M.S.; Momba, M.N.B. Groundwater quality in a South African rural community: A possible threat to public health. Pol. J. Environ. Stud. 2012, 21, 1349-1358.

42. Palamuleni, L.; Akoth, M. Physico-chemical and microbial analysis of selected borehole water in Mahikeng, South Africa. Int. J. Environ. Res. Public Health 2015, 12, 8619-8630. [CrossRef] [PubMed] 